\title{
Total chlorophyll and growth of grape rootstock 'SO4' in answer to electrical stimuli
}

\author{
Gabriela Victoria Jardim, Elizeu Nogueira Fernandes, and Juan Saavedra del Aguila ${ }^{a}$ \\ Federal University of Pampa (UNIPAMPA) - Campus Dom Pedrito - Bachelor's course in oenology, Street Vinte e Um de Abril n ${ }^{\circ} 80$, \\ Dom Pedrito, Rio Grande do Sul(RS), CEP: 96450-000, Brazil
}

\begin{abstract}
The experiment examined effects on the total chlorophyll and growth of vine rootstock 'SO4' under electrical stimulation. The study was conducted from December 2015 to March 2016 by the Core for Study, Research and Extension in Enology (NEPE ${ }^{2}$ ), in a greenhouse at the Federal University of "Pampa" (UNIPAMPA) - "Dom Pedrito" Campus. The Rootstocks 'SO4' were obtained in property located in the city of "Dom Pedrito" (RS, Brazil).The four treatments were: The first (T1) to control, no electric discharge; the second (T2) with an electric discharge of $0.02 \mathrm{~mA}$ for 5 seconds; followed by the third (T3) and fourth (T4) with times of discharge of 9 and 18 seconds respectively. The analyses were made using a chlorophyll meter. To measure chlorophyll content of the rootstock 'SO4' when subjected to electrical discharges with a $0.02 \mathrm{~mA}$ current during 9 seconds and 18 seconds applied once per week for twelve weeks.
\end{abstract}

\section{Introduction}

Science has shown that the plant is similar to the behaviour of the animals as compared to response mechanisms to the environment [1]. By submitting the plant to electrical stimuli, we supposedly promote stresses that can generate positive responses. Being that way, we can get good results by applying practices in plants similar to the electrotherapy.

Man has used the electrotherapy since ancient times with electric eels to relieve pain. Today it uses specific equipment, for depression and anxiety treatments; they use it to stimulate the nervous system, which will selectively produce amino acids, monoacid and peptides $[2,3]$.

The plants perform the information processing in a complex way; not only with action potentials, synaptic mode but also in cell-to-cell communication [4] therefore, the electrical discharges in plants can also stimulate the production of certain substances.

Within the anthropocentric view of man, the vine is a sessile organism, which means that you cannot get around as the man, having to react to the different stresses imposed by its surroundings in fantastic time speeds in order to ensure the survival of the species.

In this struggle for survival, the vine uses different types of signals in response to different stresses or specific stages of plant development; within these signs we known until now: hydraulic, chemical, neurological, mechanical and electrical.

Expanding on the electrical signals, it is known the existence of an action potential of the plasma membrane of the vine, with an average load of $-120 \mathrm{mV}$, with a modification of this electrical charge, the cell membrane will open or close various kinds of carriers proteins, as well

\footnotetext{
${ }^{a}$ Corresponding author: juanaguila@unipampa.edu.br
}

as connecting or disconnecting different types of metabolic events.

In the case of having an extreme change of the action potential membrane, it has a dramatic modification of the highly selective permeability of the plasma membrane, which inevitably leads to cell death. Principle used in electric weeding, controlling weeds through electrical discharge with a voltage around 5000V [5].

Still, slight changes in the membrane potential can be understood by the vine, as a signal that it is able to address a larger stress; acting this small electrical stimulus positively in the development of the vine, because it would be ready to respond to different stresses that the vine faces every second of its existence.

In this sense, the present study aimed to analyse responses in growth and total chlorophyll content of the rootstock vine 'SO4', when subjected to electrical discharge with $0,02 \mathrm{~mA}$ current for different periods.

\section{Material and methods}

The experiment was conducted by the Core for Study, Research and Extension in Enology $\left(\mathrm{NEPE}^{2}\right)$ in the greenhouse at the Federal University of "Pampa" (UNIPAMPA) - "Dom Pedrito" Campus, in the municipality of "Dom Pedrito" (Latitude $30^{\circ} 58^{\prime} 58^{\prime \prime} \mathrm{S}$ and Longitude 54 40 '23 "W), "Region Gaúcha" Campaign, "Rio Grande do Sul”, Brazil. The grape rootstocks 'SO4' were obtained in August 2015 on private property, in the same municipality where the experiment was conducted, we used this vine rootstock as physiological study model.

The lower third of the piles was immersed in hot water with auxin hormone $5 \mathrm{ppm}$ for 10 seconds to assist in rooting. The cuttings were planted in plastic bags with a mixture containing $50 \%$ of substrate and $50 \%$ sand, creating a more suitable environment for its development. For the application of electrical stimulus, a device was 
Table 1. Height $(\mathrm{cm})$ of the grape rootstocks 'SO4' submitted or not to the electrical discharges of $0.02 \mathrm{~mA}$. T1 - Treatment control without electrical discharges; T2 - Treatment with an electric discharge of $0.02 \mathrm{~mA}$ for 5 seconds once per week for 12 weeks; T3 Treatment with an electric discharge of $0.02 \mathrm{~mA}$ for 9 seconds once per week for 12 weeks and; $\mathrm{T} 4$ - Treatment with an electric discharge of $0.02 \mathrm{~mA}$ for 18 seconds once per week for 12 weeks.

\begin{tabular}{|l|l|l|l|l|l|l|l|l|l|l|l|l|}
\cline { 2 - 12 } \multicolumn{1}{c|}{} & We.* 1 & We. 2 & We. 3 & We. 4 & We. 5 & We. 6 & We. 7 & We. 8 & We. 9 & We. 10 & We. 11 & We. 12 \\
\hline T1 & $28.2 \mathrm{a}^{* *}$ & $31.8 \mathrm{a}$ & $34.6 \mathrm{a}$ & $36.2 \mathrm{a}$ & $37.5 \mathrm{a}$ & $37.3 \mathrm{a}$ & $36.3 \mathrm{a}$ & $36.8 \mathrm{a}$ & $36.9 \mathrm{a}$ & $39.4 \mathrm{a}$ & $39.6 \mathrm{a}$ & $39.8 \mathrm{~b}$ \\
\hline T2 & $28.5 \mathrm{a}$ & $32.4 \mathrm{a}$ & $36.6 \mathrm{a}$ & $37.9 \mathrm{a}$ & $39.3 \mathrm{a}$ & $39.3 \mathrm{a}$ & $38.9 \mathrm{a}$ & $39.2 \mathrm{a}$ & $38.7 \mathrm{a}$ & $42.3 \mathrm{a}$ & $41.1 \mathrm{a}$ & $43 \mathrm{ab}$ \\
\hline T3 & $29.3 \mathrm{a}$ & $30.9 \mathrm{a}$ & $34.1 \mathrm{a}$ & $36.3 \mathrm{a}$ & $36.7 \mathrm{a}$ & $38.1 \mathrm{a}$ & $38.6 \mathrm{a}$ & $40.1 \mathrm{a}$ & $41.7 \mathrm{a}$ & $44.6 \mathrm{a}$ & $45.3 \mathrm{a}$ & $46.5 \mathrm{a}$ \\
\hline T4 & $28 \mathrm{a}$ & $28.5 \mathrm{a}$ & $30 \mathrm{a}$ & $31.1 \mathrm{a}$ & $32 \mathrm{a}$ & $32.1 \mathrm{a}$ & $32.5 \mathrm{a}$ & $34.3 \mathrm{a}$ & $36.1 \mathrm{a}$ & $39.6 \mathrm{a}$ & $42.4 \mathrm{a}$ & $41.9 \mathrm{ab}$ \\
\hline
\end{tabular}

$*$ We. = week. **Equal letters in the column do not differ statistically by Tukey test at $5 \%$ probability.

Table 2. Total Chlorophyll of the grape rootstocks 'SO4' submitted or not to electrical discharges of $0.02 \mathrm{~mA}$. T1 - Treatment control without electrical discharges; T2 - Treatment with an electric discharge of $0.02 \mathrm{~mA}$ for 5 seconds once per week for 12 weeks; T3 Treatment with an electric discharge of $0.02 \mathrm{~mA}$ for 9 seconds once per week for 12 weeks and; T4 - - Treatment with an electric discharge of $0.02 \mathrm{~mA}$ for 18 seconds once per week for 12 weeks.

\begin{tabular}{|c|c|c|c|c|c|c|}
\cline { 2 - 7 } \multicolumn{1}{c|}{} & $\mathbf{1}^{*}$ & $\mathbf{2}$ & $\mathbf{3}$ & $\mathbf{4}$ & $\mathbf{5}$ & $\mathbf{6}$ \\
\hline T1 & $300.2 \mathrm{a} *$ & $253.6 \mathrm{a}$ & $254.5 \mathrm{c}$ & $250.5 \mathrm{ab}$ & $240.5 \mathrm{ab}$ & $215.6 \mathrm{c}$ \\
\hline T2 & $324.4 \mathrm{a}$ & $299.8 \mathrm{a}$ & $267.7 \mathrm{bc}$ & $242.8 \mathrm{~b}$ & $237.2 \mathrm{~b}$ & $230.9 \mathrm{bc}$ \\
\hline T3 & $286.4 \mathrm{a}$ & $293.7 \mathrm{a}$ & $288.9 \mathrm{ab}$ & $268.3 \mathrm{ab}$ & $264.1 \mathrm{ab}$ & $254.12 \mathrm{~b}$ \\
\hline T4 & $294.3 \mathrm{a}$ & $293.1 \mathrm{a}$ & $303.7 \mathrm{a}$ & $279.1 \mathrm{a}$ & $284.6 \mathrm{a}$ & $272.2 \mathrm{a}$ \\
\hline
\end{tabular}

$* 1$ - Corresponds to the date of analysis: $12 / 17 / 2015 ; 2$ - Corresponds to the date of analysis: $12 / 24 / 2015 ; 3$ - Corresponds to the date of analysis: $01 / 21 / 2016$; 4 - Corresponds to the date of analysis: 02/04/2016; 5 - Corresponds to the date of analysis: 02/18/2016 e; 6 - Corresponds to the date of analysis: $03 / 03 / 2016$. ** Equal letters in the column do not differ statistically by Tukey test at $5 \%$ probability.

adapted to function as an energized capacitor; accordingly, a discharge occurs with $0.02 \mathrm{~mA}$ chain by touching its two poles (positive and negative) on the vine. The current is continuously and was measured by a digital ammeter. A key continuity was also used, and leaning against the plant in shock time of application for certification that the current passed. We selected 4 treatments with 4 repetitions, each repetition with 7 plants totaling 28 plants per treatment. The treatments were: The first (T1) to control, no electric discharge, the second (T2) with an electric discharge of $0.02 \mathrm{~mA}$ for 5 seconds, followed by the third (T3) and fourth (T4) with times of discharge of 9 and 18 seconds respectively. The treatments were applied from December 2015, once a week for 12 consecutive weeks.

We analysed the growth, measuring the height using a ruler graduated in centimetres being analysed 1 time per week for 12 weeks between December 2015 and March 2016. It was also analysed chlorophyll using a chlorophyll meter (FalkerclorofiLOG ${ }^{\circledR}$ ) 1 once a week for six weeks between December 2015 and March 2016.

The results were submitted to analysis of variance (ANOVA) and the average were compared by the comparison test averages of Tukey at 5\% probability [6-8].

\section{Results and discussions}

For growth, the plant height with treatment with electrical discharge for 9 seconds (current $0.02 \mathrm{~mA}$ ) once a week for 12 weeks (T3) in the last evaluation was statistically higher than the height of the control plants (T1) who received no electrical stimulation (Table 1). However, it is necessary to further studies to analyse the effect of electrical stimulation on the vine rootstock growth, considering that the statistical difference appeared only in the last week of trial.
The treatment with electric discharge for 18 seconds (current $0.02 \mathrm{~mA}$ ) once a week for 12 weeks (T4), showed the highest amount of chlorophyll of all treatments, superior to T1, as well as the treatment with 9 seconds discharges (current $0.02 \mathrm{~mA}$ ) once per week for 12 weeks (T3 was also above of the T1, but less than T4. The treatment with 5 seconds electric discharges (current $0.02 \mathrm{~mA}$ ) once per week for 12 weeks (T2), was similar to the control (T1 and T3 (Table 2).

The use of direct electric current has already demonstrated some positive results. There was an experiment in the United States Department of Agriculture (USDA) in 1964, with the use of a negative electrode positioned in the shoot of a tree, a connected positive on a nail at the base of it and 60 volts stimulus. The electrified branches had substantially increased leaves after 1 month and at the end of one year, the foliage on them increased $300 \%$ [9].

\section{Conclusions}

It concluded preliminarily that the vine rootstocks 'SO4', when subjected to electrical stimuli with discharges, for 18 seconds with a current of $0.02 \mathrm{~mA}$, once per week in 12 weeks, have a tendency to higher content of chlorophyll.

We would like to thank to the wine grower Mr. Adair Camponogara.

\section{References}

[1] F. Baluška, S. Mancuso, Plant Neurobiology (Corner, 2009)

[2] T. H. Barclay, R. D. Barclay, A Clinical Trial of Cranial Electrotherapy Stimulation for anxiety and comorbid (Journal of Affective Disorders, 164, 2014) 
[3] A. J. R. Macdonald, Acupuncture in Medicine, BMJ. v.11, p.66 (1993)

[4] F. Baluška, et al. Neurobiological View of Plants and Their Body Plan,Springer-Verlag, Berlin, Heidelberg (2006)

[5] A. M. Brighenti, et al. Controle de plantas daninhas em cultivos orgânicos de soja por meio de descargas elétricas, Brasil, Ciência Rural, v.39, n.8, p. 2315-2319 (2009)

[6] J. Saavedra delAguila; A.P. Dachi; E.N. Fernandes; B.L. Hamm; F.C. de Almeida; J.M. Silveira. Garlic and $\mathrm{H}_{2} \mathrm{O}_{2}$ in overcoming dormancy on the vine 'Cabernet Sauvignon', France, Bio Web of Conferences, v.5, p. 3 (2015)
[7] J. Saavedra del Aguila; A. Zanella; A.D. Pinheiro; A.M. dos Santos; E.B. Radmann; L.S. Heiffig-del Aguila, Woody cuttings of 'Niagara Rosada' and 'Niagara Branca' rustic grapes. Wageningen, Holanda. ActaHorticulturae. v.1115, p. 249-252 (2016)

[8] F.C. de Almeida; J.F.L. de C. Cham; B.L. Hamm; S.M. Ferreira; M. Gabbardo; J. Saavedra delAguila. Use of plant growth regulation in the conservation of grapes 'Italy' as aid postharvest, France, Bio Web of Conferences, v.3, p. 4 (2014)

[9] A. M. Rodrigues, Eletrocultura, Instituto Anima, www. institutoanima.org/Downloads / Eletrocultura.doc 09/14/2016 